\title{
MENTORING AS A MEDIATING FACTOR FOR EFFICACIOUS LEADERSHIP DEVELOPMENT
}

\begin{abstract}
The purpose of this study was to explore the phenomenon of leadership development as experienced by nongovernment organization (NGO) executive leaders in international agricultural development. Data were collected from twelve executive NGO leaders through in-depth interviews to understand the textural and structural essences of the participants' lived experiences of leadership development. Findings indicated the integral role of mentoring in leadership development prior to obtaining an executive leadership role and supported the conceptual model inclusive of mentoring as a mediating factor of efficacious leadership development. The study provided implications and future research recommendations for executive leaders in international agricultural development, as well as for leadership educators and practitioners.
\end{abstract}

\section{Introduction}

Internationalization, globalization, and other terminologies have been readily referenced throughout our world today. Regardless of the terminology, the common emphasis has remained on the key result of a high-paced, intensive, and connected livelihood (Payne, 2013). With a growing population expected to reach beyond 9 billion people by the year 2050 (Food and Agriculture Organization of the United Nations [FAO], 2015), agriculture has been the focus of conversations among a diverse set of contexts, including international development. To meet this challenge and multiple facets of sustainable development (United Nations [UN], 2015), additional leaders within all aspects of international agricultural development are needed. According to Lewis and Opoku-Mensah (2006), "NGOs remain as an important and large-scale presence on the landscape of international development" (p. 665-666).
Additionally, Caligiuri and Dragoni (2015) stated, "The concern regarding the short supply of global leaders is exacerbated by the speed in which future leaders will need to be developed" (p. 226). While specific contextual research has been conducted regarding the role of leadership self-efficacy in Latina leaders in higher education (Montas-Hunter, 2012), educators and students (Bang \& Reio, 2017; Phan \& Locke, 2015), career advancement of women coaches (Machida \& Feltz, 2013), business leaders (Javadin et al., 2016; Paglis \& Green, 2002; Walumbwa et al., 2005), and women leaders in the credit union industry (Garmon, 2007), no research was found within the field of international agricultural development. Thus, research is needed to explore the lived leadership development experiences of NGO executive leaders in international agricultural development.

The purpose of this study was to explore the essence of lived leadership development experiences by NGO executive leaders in international agricultural 
development. The objectives of this study were to: 1) Describe the leadership development experiences of organizational executive leaders in international agricultural development and 2) Identify the structural essence of self-efficacy expectations and influences on leadership development experiences of organizational executive leaders in international agricultural development. Consideration of contextual and individual differences that impact a leader's self-efficacy through developmental experiences is imperative (Machida \& Schaubroeck, 2011). Thus, through in-depth qualitative interviews that explored the phenomenon of leadership development in executive leaders of international agricultural development NGOs and data analyses, this study explored the common themes of leadership development experiences and the implications of leader self-efficacy to leader development.

\section{Literature Review}

Leadership development is defined as "the expansion ofthecapacityofindividualstobeeffectiveinleadership roles and processes" (Day \& Dragoni, 2015, p. 134). Leadership is a common interest for organizations, and leadership development is more about effectiveness and efficiency than a particular model (Day et al., 2014). Reichard et al. (2017) recommended additional considerations of organizational context and barriers to leader development; however, the researchers implored, "Leaders must continue to develop in order to tackle the complex problem facing their organizations" (p. 152). Day and Dragoni (2015) stated, "The phenomenon of leadership development is complex and has implications at the individual, dyadic, team, and organizational levels of analysis, as well as longitudinally" (p. 149). Additional research is needed within specific contexts to observe the contextual applications of best practices for leadership development (Dragoni et al., 2014; Machida \& Schaubroeck, 2011; Petridou et al., 2017). Hannah et al. (2008) concluded, "As the field of leadership development moves forward by building interventions based on well tested theory, we expect that focusing on leadership self-efficacy will enhance the impact of such interventions on leader and follower development" (p. 688).

\section{Leadership Development and Self- Efficacy}

According to Paglis and Green (2002), "Leadership self-efficacy is a person's judgement that he or she can successfully exert leadership by setting a direction for the work group" (p. 217). Self-efficacy beliefs may play an important role in leadership development, yet the development of a model or theory to connect this process is lacking (Machida \& Schaubroeck, 2011). Walumbwa et al. (2005) echoed, "Indeed, the link between efficacy, effort and performance is perhaps one of the best established relationships in the behavioral sciences" (p. 3), yet they emphasized that more training and development is needed to address the complex and integral role of self-efficacy in leadership. Garmon (2007) explored the relationship between selfefficacy and career development to provide insight into strengthening self-efficacy antecedents that may influence leadership development. Antecedents in this study were categorized according to Bandura's (1977; 1998) self-efficacy antecedent framework: mastery experiences, social models, verbal persuasion, and physiological and affective states. Chan and Drasgow (2001) suggested that leader development may link various antecedents (e.g. cognitive ability, personality, leadership experience, values) to leadership performance.

The complexity of leadership in the midst of global and local challenges demands both context specific and broad application skills to be consistently developed and refined in communities and organizations; such factors and opportunities impact a leader's decision to lead change within a specific context (Chan \& Drasgow, 2001; Bandura, 1998). Walumbwa et al. (2005) expanded the thought of self-efficacy's influence from activity choice to its potential impact on overall performance outcomes. A strong sense of efficacy is required to apply one's skills to their fullest and remain focused on the tasks at hand 
when faced with the challenges of global issues, cultural differences, and difficult circumstances for implementing change initiatives (Wood \& Bandura, 1989).

\section{Mentoring}

Lester et al. (2011) explored the impact of mentorship in leader development, noting, "We suggest that leader efficacy is a critical component in leader development, and moreover an aspect of leadership that can be effectively developed in the mentorprotégé relationship" (p. 411). Additionally, Siebert et al. (2017) examined the mediating role of leadership self-efficacy and a mentor network toward leader effectiveness through development experiences. Mentoring also served as an encouragement for creative expression and approaches to work (Bang \& Reio, 2017). According to Lester et al. (2011), "Indeed, the assumption that having a good mentor is essential to one's career success as a leader is ubiquitous in career counseling, yet there is little empirical evidence to justify this assumption" ( $p$. 409). Though in a specific military context, Lester et al. (2011) proposed future research to further explore the potential impact of mentoring on leadership efficacy. Siebert et al. (2017) also called for additional research to expand upon the role of a mentor network through leadership self-efficacy development in job challenges within professional dyads of retail managers and supervisors

\section{Theoretical/Conceptual Framework}

In order to explore self-efficacy and leadership development, the researchers created a conceptual model to show the application of Bandura's (1986) Model of Reciprocal Determinism to the context of executive NGO leadership development within international agricultural development (Figure 1). The concept of reciprocal determinism posits that personal, behavioral, and environmental factors interact with each other; thus, the foundation of the conceptual model reflected McCormick's (2001) application of Bandura's (1986) model to include the Leadership Environment, Leadership Behaviors, and Leadership Cognitions and Other Personal Factors. Centered within the triad was the phenomenon of interest for this study, Leadership Development.

Within this conceptual model, the leadership

\section{Figure 1}

Conceptual Model of Mediating Practices for Leadership Development

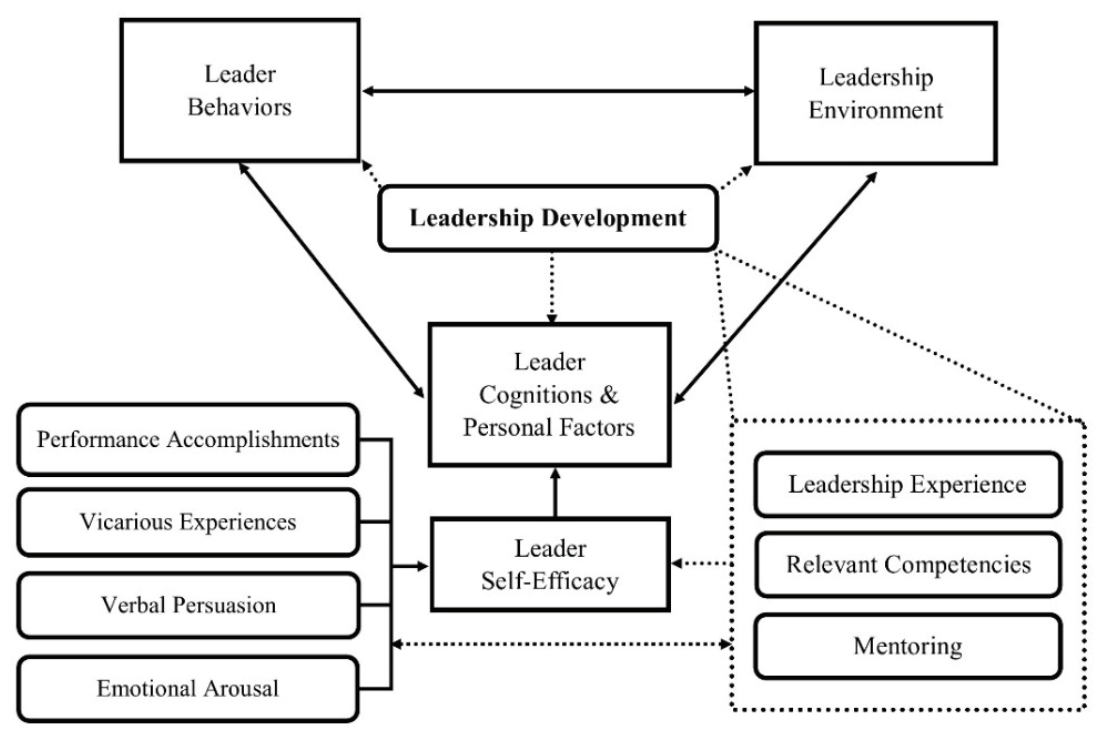


environment reflected a broad understanding of international agricultural development work. Additionally, the leadership environment presented potential organizational challenges or barriers for executive leaders regarding leadership development efforts. Leadership behaviors within the conceptual model reflected the competencies needed to effectively lead within this complex leadership environment. This element is connected to both the leadership environment, leadership cognitions, and personal factors. Leader cognition and personal factors of the reciprocal causation structure were concerned with role of self-efficacy to the social cognitive process and specific inquiry to the impact of various efficacy expectations (Bandura, 1977) on leadership development. McCormick's (2001) Social Cognitive Model of Leadership identified leader selfefficacy as an integral component to leader cognition, and Paglis and Green's (2002) model provided insight to the importance of self-efficacy to leadership development. Bandura's (1977) four efficacy expectations are listed within the conceptual model as a direct impact on overall leader self-efficacy. The focus of this study was the conceptualization of mediating practices between integrative cognitive processing of efficacy expectations and leadership development. Mediating practices reflected both cognitive and behavioral processes of leadership development, highlighting Bandura's (1977) Social Learning Theory connections between cognition and behavior. Based upon Bandura's (1977) efficacy expectations, McCormick's (2001) leader cognition and other personal resources, and Paglis and Green's (2002) antecedents of leadership self-efficacy, three mediating practices were identified for exploration: leadership experience, relevant competencies, and mentoring. These three mediating practices provided the inquiry structure for this study; the triadic elements offered the structure for exploring the various influences on leadership development through participants' lived experiences.

\section{Methods}

This study used phenomenology in theoretical foundation and methodological practice to explore the phenomenon of leadership development in international agricultural development through the lens of executive leaders in non-government organizations. Creswell (2013) described, "The basic purpose of phenomenology is to reduce individual experiences with a phenomenon to a description of the universal essence" (p. 76). Phenomenology is characterized by emphasis on a particular phenomenon, explored within a group of three to 15 people, with focus on lived experiences and the researcher previously identifying and setting aside experiences with the phenomenon (Creswell, 2013). A transcendental/descriptive phenomenological approach was utilized in this study to minimize bias in describing leadership development experiences of executive organizational leaders and inquiry of common mediating practices toward leadership development within international agricultural development non-government organization executives (Creswell, 2013).

Participants for this study were selected initially through criterion criterion sampling (Creswell, 2013). Participants met the following criteria: hold an executive leadership position in a U.S.-based non-government organization, be employed by an organization conducting international agricultural development work, and be willing to share about their personal leadership development experiences within international agricultural development. These criteria enabled me to capture the phenomenon of leadership development experiences and various influences of leader self-efficacy through focus on the level of leadership with the greatest responsibility for directing development work and creating a culture where leadership growth is possible to sustain the organization's work into the future. The essence of executive leader development experiences may influence the degree to which challenges are met with efficacious belief and establish common needs 
for sustained leadership development in the field of international agricultural development.

Twelve executive leaders (i.e. Chief Executive Officer, President, Executive Director, etc.) of non-government organizations that are engaged in international development work participated in this study. Additional participants were selected by snowball sampling (Creswell, 2013), with each participant asked at the end of their interview to recommend other executive leaders in international agricultural development to contact. Participants were assigned pseudonyms through an online name generator to maintain anonymity (Table 1). Demographic and academic information is reflected in Table 1.

Table 1.

Participant Profiles

\begin{tabular}{llllll} 
Participant & Pseudonym & Gender & Age & Education & Degree \\
\hline Participant 1 & Cornell & M & $56+$ & Master's & Agricultural Education \\
\hline Participant 2 & Stan & M & $46-55$ & Master's & International Development \\
\hline Participant 3 & Randell & M & $56+$ & High School & n/a \\
\hline Participant 4 & Stuart & M & $46-55$ & Master's & International Relations \\
\hline Participant 5 & Dale & M & $56+$ & Master's & Public Policy \\
\hline Participant 6 & Mark & M & $46-55$ & Bachelor's & Philosophy \& Spanish \\
\hline Participant 7 & Felicia & F & $46-55$ & Bachelor's & International Affairs \& \\
\hline Participant 8 & Casey & M & $35-45$ & Doctorate & Aquaculture \& Extension \\
\hline Participant 9 & Matt & M & $46-55$ & Bachelor's & Mathematics \\
\hline Participant 10 & Rachel & F & $35-45$ & Bachelor's & International Studies \\
\hline Participant 11 & Rochelle & F & $35-45$ & Bachelor's & Political Science \& English \\
\hline Participant 12 & Alan & M & $56+$ & High School & n/a \\
\hline
\end{tabular}

Tenure of the executive leader and founder status are reflected in Table 2. Additional organizational information, including founding year, gross income, and staff size are also represented in Table 2 . Organizational information was obtained through Guidestar and IRS-990 reports to demonstrate variability in the purposive sample. Though not explicitly stated for security reasons, 11 of the 13 organizations in this study were noted through participant interviews to have faith-based foundations undergirding the efforts in international agricultural development. Qualitative research recognizes the researcher as the primary instrument of data collection (Seidman, 2013). As a researcher of leadership in international agricultural development, personal experiences through international travel, missions, and a rural upbringing shape my research focus. Ary et al. (2010) emphasized, "Although you should be interested, perhaps even passionate, about your topic, you must not be so emotionally involved that your own biases prevent you from adequate interpretation of the findings" (p. 587). My interests lie in the effectiveness of international agricultural development organizations serving around the world in some of the hardest locations, and in both the needs and practices surrounding organizational leadership and leadership development for sustained impact.

The interview protocol was based upon Garmon's (2007) research on self-efficacy and women leaders, 
Table 2.

Executive Organizational Tenure and Organizational Profiles

\begin{tabular}{llllll} 
Organization & Role Tenure & Founder & Founded & Gross Receipts & Paid Staff \\
\hline Organization 1 & 11 years + & $\mathrm{N}$ & 1993 & $\$ 2,000,001-\$ 5$ million & 23 \\
\hline Organization 1a & 11 years + & $\mathrm{Y}$ & 1995 & $<\$ 500,000$ & 0 \\
\hline Organization 2 & $5-10$ years & $\mathrm{Y}$ & 2009 & $\$ 500,001-\$ 2$ million & 7 \\
\hline Organization 3 & $5-10$ years & $\mathrm{Y}$ & 2012 & $<\$ 500,000$ & 1 \\
\hline Organization 4 & 11 years + & $\mathrm{N}$ & 1984 & $\$ 2,000,001-\$ 5$ million & 17 \\
\hline Organization 5 & $<4$ years & $\mathrm{N}$ & 1973 & $\$ 2,000,001-\$ 5$ million & 76 \\
\hline Organization 6 & $<4$ years & $\mathrm{N}$ & 1995 & $\$ 2,000,001-\$ 5$ million & 9 \\
\hline Organization 7 & 11 years + & $\mathrm{Y}$ & 1997 & $\$ 500,001-\$ 2$ million & 8 \\
\hline Organization 8 & 11 years + & $\mathrm{Y}$ & 2005 & $<\$ 500,000$ & 3 \\
\hline Organization 9 & 11 years + & $\mathrm{N}$ & 1999 & $\$ 2,000,001-\$ 5$ million & 11 \\
\hline Organization 10 & $<4$ years & $\mathrm{N}$ & 1976 & $<\$ 500,000$ & 31 \\
\hline Organization 11 & $<4$ years & $\mathrm{N}$ & 2004 & $\$ 500,001-\$ 2$ million & 11 \\
\hline Organization 12 & 11 years + & $\mathrm{Y}$ & 2006 & $<\$ 500,000$ & 0 \\
\hline
\end{tabular}

as the protocol built upon prior research and reflected the various antecedents represented in the conceptual model for this study. Open-ended questions were included in the protocol to explore the lived experiences of the participants and minimize the guidance of the researcher in the reconstruction of experience with the phenomenon (Seidman, 2013). Various questions were included to address the elements of the conceptual model to gain an indepth understanding of the leadership environment, leader behaviors, and leader cognitions, as well as the mediating practices of leadership experiences, needed competencies, and mentoring.

\section{Data Collection}

Approval for this study was received from the institutional Internal Review Board as an exemptstudy. Data were collected through in-depth personal, semistructured interviews (Ball, 2017). Interview questions were carefully designed to address the points of inquiry for this study, and questions were structured as open-ended to enable informal, interactive aspects of the phenomenological interview process (Moustakas, 1994). Due to the nature of executive organizational leaders' time constraints, a single indepth interview was conducted, ranging from 35 to 75 minutes in length (Ball, 2017; Nyukorong \& Quisenberry, 2016). Due to the various locations of participants across the United States, participants were provided with web or phone access information to join a GoToMeeting session at the designated interview time. Interviews were conducted between February 3, 2017 and May 24, 2017. Though snowball and criterion sampling enable variation for a study, the researcher must recognize when enough data has been collected to understand the phenomenon of interest (Seidman, 2013). The researcher noted the emergence of similarities from participant responses with participants seven and eight. Saturation of the data was further confirmed through the remaining interviews of the study. Participants were also added to sufficiently reflect a range of gender, age, and experience levels. Interviews were recorded through 
GoToMeeting, converted to MP4 files, and then sent to a third-party transcription service.

\section{Data Analysis}

According to Moustakas (1994), "In accordance with phenomenological principles, scientific investigation is valid when the knowledge sought is arrived at through descriptions that make possible an understanding of the meanings and essences of experience" (p. 84). Transcripts were systematically reviewed for themes and key descriptors to determine the essence of the phenomenon following Creswell's (2013) prescribed seven step method (adapted from Moustakas, 1994). The first step is to describe personal experiences with the phenomenon of interest (epoche). For this study, the researcher recorded assumptions, connections, and experiences with each objective, as well as recorded the researcher subjectivity statement to provide readers with an accurate portrayal of bracketed biases. The second step is to develop a list of non-repetitive, significant statements (horizonalization). Interview transcripts for this study were reviewed in accordance to the objectives of the study. Significant statements were highlighted in the respective objective color. The third step is to group the significant statements into themes (clustering). Significant statements in this study were reviewed by participants and transferred to a spreadsheet. A meaning statement was assigned for each significant statement. The fourth step is to create an "individual textural description" of the experience for each participant. Significant statements for objective one were reviewed for each individual and a summary textural statement was composed. Fifth, researchers should develop an "individual structural description" for each participant and a summary structural statement. Sixth, researchers should develop an "individual texturalstructural description" for each participant (essence). The statements were combined and sent to individual participants for member checking to occur. The seventh step is to determine the meaning and essence(s) of the phenomenon of interest through a composite texturalstructural description. To establish the composite essence of leadership development within the context of this study, significant statements were grouped by objective into tabs of a spreadsheet, printed and manually separated, then individually reviewed and clustered according to similarities among the participants. Each cluster of responses were then assigned a theme, as well as clustered into subthemes when appropriate. Themes and subthemes were recorded in the spreadsheet for ease of sorting and future reference. The essence was developed through the emergent themes and subthemes of the data.

This study engaged several strategies identified by Guba (1981) to strengthen the trustworthiness of the findings, including the following: member checks (credibility); triangulation and researcher journal (transferability); interview guide, audio recording of the interviews, and coding by one researcher within a condensed time frame (dependability); and an audit trail (confirmability). Guba (1981) noted that methodology presumes objectivity, but presumptions aside, qualitative researchers address this concern for trustworthiness by stating their bias, specifically through the epoche and bracketing within phenomenological research, and by focusing on the confirmability of the data collected.

\section{Results}

Following the individual participant analysis, significant statements were separated in an Excel spreadsheet by objective. The initial 127 significant statements were analyzed through a manual sorting process to identify common experiences of the phenomenon. Three chronologically framed themes were identified: past leadership development experiences, current leadership development practices, and leadership development practices for future leaders. Eleven subthemes were identified within the three themes (Table 3).

\section{Past Leadership Development Experiences}

The first theme recognized past leadership development experiences and reflected the various lived experiences of NGO executive leaders that were formative in their journey to an executive leadership position. Four 
Table 3.

Themes and Related Subthemes

\begin{tabular}{llc}
\hline $\begin{array}{l}\text { Theme } \\
\text { Past Leadership Development }\end{array}$ & Related Subtheme(s) & Freq. \\
\hline & Professional Experiences & 7 \\
\hline & Educational Experiences & 5 \\
\hline & Formative Experiences & 9 \\
\hline $\begin{array}{l}\text { Current Leadership Development } \\
\text { Practices }\end{array}$ & Mentoring Experiences & 8 \\
\hline & Self-directed Learning & 9 \\
\hline & Formal Learning Opportunities & 5 \\
\hline & On-the-job Experiences & 3 \\
\hline & Mentoring Needs & 5 \\
\hline $\begin{array}{l}\text { Leadership Development Practices for } \\
\text { Future Leaders }\end{array}$ & Establishing a Community or Network & 6 \\
\hline & Empowerment of staff \& others toward development & 7 \\
\hline Organization 11 & Opportunities for the next generation & 8 \\
\hline Organization 12 & $\$ 500,001$ - \$2 million & 11 \\
\hline
\end{tabular}

subthemes were identified from the data regarding these developmental experiences: professional experiences, educational experiences, formative experiences, and mentoring experiences.

\section{Professional Experiences}

The first subtheme focused on work experiences prior to the participant's executive leadership role. Half of the participants noted having experience in the international agricultural development field prior to their executive role. While one executive director, Rochelle, noted, "Professionally, I have never had any formal managerial responsibilities prior to coming here," other participants like Randell expressed having "quite a bit of management experience especially in the small organization level." Stan recognized the transferability of skills from the professional experiences on his leadership development path to be an executive director. Stan shared, "I had worked coordinating sort of grassroots community-level development as well as some policy work, so some direct engagement in that as well as some management functions." While participant experiences varied greatly, the lasting impact of their professional experiences was shared.

\section{Educational Experiences}

The second subtheme identified within the frame of past experiences was educational experiences. Educational experiences offered opportunities for participants to develop as leaders with content knowledge and practical applications. Half of the participants shared either an international component to their formal degree work or a formal degree connected to agriculture. These formal educational experiences helped shape the approaches to international agricultural development work, particularly for Rachel who said, "I would say that I probably come at agricultural development more from a community health perspective and a political 
systems perspective. Even one course can make a lasting impact." Randell reflected on a perspectives course he and his wife took: "We took a course that changed our lives as far as our view of the world and all the different people, people groups that populate it now and have populated it over time." Educational experiences provided meaningful points within several participants' leadership development.

\section{Formative Experiences}

The next subtheme, formative experiences, was identified as a complimentary theme to both the professional experiences and educational experiences. It expressed the moments that guided participants to find their pathway within international agricultural development work. For six of the 12 participants, formative experiences also shaped how the organization he or she leads began. Stan shared, "We knew from the beginning that creating an organization has lots of challenges and demands," yet he pressed forward for a cause. Cornell founded his organization after seeing a need while traveling, then seeking unsuccessfully to find an organization to serve that need:

The first time I went to Kenya, I guess two things that stuck in my mind were the lack of water and the fact that so many people were drinking contaminated water. And so that was an immediate thing, how can I help to solve that problem and then the other problem was malnutrition and hunger and so actually how I got involved in that was trying to find somebody else to do it.

Formative experiences such as this played integral roles in motivating participants along their leadership development journeys.

\section{Mentoring Experiences}

The final subtheme identified within the past leadership development experiences theme was mentoring experiences. Participants overwhelmingly noted the impact of mentors toward their leadership development over the years. Regarding serving in a manner that respect, honors, and brings dignity to those being served, Matt noted, "I've had some great mentors over the years that have modeled that for me." Dale reflected on a key mentor who inspired Dale's work when he shared, "He was a guy who had deep and profound wisdom. He was brilliant, he'd honestly had a lot of life experience." Felicia commented, "A lot of people seem to have one key mentor. And I don't feel like I've had that so much. I've had a number of people that I've learned from." Other participants, like Rochelle, recalled specific mentors who helped in their leadership development, such as this participant's reflection:

Oh absolutely. In some ways, almost too many to count. Going back to when I was on the Hill, our legislative director was just an amazing woman and really helped me not make some of those early career missteps and there was another woman who actually, she was a lobbyist, but she continues to be a friend and a mentor just sort of digging through things and helping to think beyond sort of what's right in front of you and to the bigger picture.

Whether a single individual or multiple people investing in their lives, participants experienced the deep value of mentoring toward leadership development.

\section{Current Leadership Development Practices}

The next theme identified, current leadership development practices, demonstrated the efforts executive NGO leaders are making to continue development within their role. Five subthemes emerged from the data concerning developmental practices.

\section{Self-Directed Learning}

The first subtheme identified from the data was 
self-directed learning. An attitude of desired continued improvement was sensed from the participants. Some participants like Cornell directly stated this desire: "I'm seeking ways to improve my leadership." Participants noted the primary means of self-directed learning is reading. Stuart said, "I would say the biggest is reading, making sure I'm trying to stay up with both literature and conversations." Dale noted the importance of reading as a leader:

One is to practice what I teach or preach about being a learner, by reading and listening, recognizing that there is no area of my leadership or expertise that there isn't more that I can learn and that sometimes important things can be learned from the most unexpected teachers. So that's a big thing.

These self-directed means of leadership development offer flexibility for continued learning amidst the numerous responsibilities of executive leaders.

\section{Formal Learning Opportunities}

The next subtheme identified from the data was formal learning opportunities. Cornell noted staff retreats and weekly staff conferences as expected means of consistent, structured leadership development. Randell shared, "A number of different courses I've taken are very specific to what I do...into the agricultural side, I've taken a couple of courses at ECHO." Regarding the benefit of a formal coach, Rochelle enthusiastically shared:

I've actually been working with an executive coach for the last year and a half. . . He's been great in just sort of thinking through how to approach tricky situations or things that I can be doing to more effectively lead the team. So that's been very, very valuable.

Formal opportunities provide leadership development for those who have financial means and time access to such events and trainings.

\section{On-the-Job Experiences} really well and that I invite to speak into my life and I've shared with them. I have been looking for others, now that I've kind of been in this for a while and settling into this place and this role a little bit, I've been looking for other people that are in comparable situations that might be good sounding boards, kind of resource for me and so I've met with a few people because it's an investment of time and energy which is in scarce supply.
Another identified subtheme was related to the impact of on-the-job experience as integral to leadership development within the executive leader role of an NGO in international agricultural development. Stan emphasized the importance of on-the-job development That sort of practical hands-on learning by doing approach is, I think in our case, essential that we're doing sort of grassroots bottom-up rural development. Overall, it's kind of learning by doing and reaching out to and ask advice from different people.

On-the-job experiences offer accessible and relevant opportunities for leadership development within the specific context in which the executive leader works.

\section{Mentoring Needs}

The next subtheme identified from the data focused on mentoring needs within the NGO executive leader role. Participants like Stan expressed that in addition to the who's done it and could mentor and point to solutions in different ways, I think, could be valuable." A shared sentiment among participants was the struggle early on in the executive role. Stuart noted, "Especially in those early years, I was kind of floundering . . . way too many of the lessons I've learned, I've learned the hard way." Casey echoed, "It was a horrible stumbling through the woods trying to figure out all the $501 \mathrm{c} 3$ issues." Dale shared the challenging process of finding that valued mentor within a NGO executive leader role:

I have a couple people in my life that know me accumulated practical skills for the job, "Having somebody 
While the need is often recognized for mentors, a key challenge is connecting with individuals who share the executive level experience.

\section{Establishing a Community or Network}

The final subtheme identified within the current leadership development practices theme was establishing a community or network. With limited key mentors, they are able to connect to the challenges of executive, nonprofit leaders, peer networks enable a community of support for continued leadership development and growth. Randell shared:

I really think we spend an awful lot of energy reinventing the wheel, and you know how there is a certain amount of figuring it out on your own that has to happen because we're all unique individuals, but we don't have to learn everything the hard way.

Dale said, "Having important, valuable people in my life that I listen to and share with is an important part of continuing to learn and grow and staying teachable." He added, "There are a couple of networks that just make sense to be a part of." The Accord Network, IndigDev, Opportunity Collaboration, and InterAction were all professional networks mentioned by participants. Establishing a network or community within executive leaders who share contexts of work is invaluable to executive leader growth.

\section{Leadership Development Practices for Future Leaders}

The final theme identified, leadership development practices for future leaders, provided insight into what NGO executive leaders are doing to enable the development of leadership for the future of their organizations. Two subthemes emerged from the data regarding developmental practices for future leaders: empowerment of staff and others toward development, and opportunities for the next generation.

\section{Empowerment of Staff and Others Toward Development}

The first subtheme identified from the data was empowerment of staff and others toward development. Empowerment of others comes in the form of belief for change for Matt, who shared, "I know every person has the ability to implement or lead change in their own lives or in the lives of their family or the community or their company or whatever they happen to be affiliated with." For several participants, the people around them include the organizational staff who should be invested in ensuring the longevity of the organization, even in the midst of challenges. Felicia shared, "We offer opportunities for all of our staff to develop their skills, but it's often tight. And everybody always has twice as much work to do as time in a day to do it." Empowering staff and others toward development creates a pathway of leadership for others to continue the strong work of the organization.

\section{Opportunities for the Next Generation}

The other subtheme identified from the data was opportunities for the next generation. Several participants noted internship programs within their organization that offer opportunities to introduce young professionals or college students to international agricultural development work at its most basic form. Rachel shared:

The intern program ... [will] mentor them as individuals, and so we talk through like, big picture dreams and goals and then, like... what they want to do to achieve them, like this year, you know.

Randell said, "For moving our organization forward, we're always looking to replicate ourselves ... even though our financial resources are limited, our human resources are growing." Investing in the next generation of leaders enables a line of leaders to emerge, as well as to keep connected to the rising generation filled with innovative ideas for the industry. 


\section{The Essence of Leadership Development}

Moustakas (1994) noted, "The final step in the phenomenological research process is the intuitive integration of the fundamental textural and structural descriptions into a unified statement of the essences of the experience of the phenomenon as a whole" (p. 100). He also emphasized:

The essences of any experience are never totally exhausted. The fundamental textural-structural synthesis represents the essences at a particular time and place from the vantage point of an individual researcher following an exhaustive imaginative and reflective study of the phenomenon. (Moustakas, 1994, p. 100)

The following reflects the essence of lived leadership development experiences of executive leaders in international agricultural development.

Leadership development within the context of international agricultural development was experienced by executive NGO leader participants through various past professional and educational paths, all preparing individuals with relevant competencies and experiences for their current leadership role. Participants shared many formative experiences that directed their interests to the international agricultural development arena. Mentoring also played an integral role in participants' leadership development. Current practices for continued leadership development rely heavily on self-directed learning. Though an expressed desire for mentoring within the executive role, executive leadership development is primarily pursued through establishing a support network of trusted colleagues and peers. Leadership development practices are reciprocated through various opportunities offered to rising staff leaders to empower and encourage further development, as well as the next generation of leaders, through internships.

Through the lens of leadership cognitions and personal factors, self-efficacy for the executive
NGO leader is integrated through numerous sources of performance accomplishments, vicarious experiences, verbal persuasion, and emotional arousal. Prior professional and personal experiences enabled contributing performance accomplishments toward positive, efficacious leadership development belief. Learning through colleagues and mentors provided vicarious experiences that brought belief for taking on unknown arenas. Verbal persuasion from trusted sources encouraged leadership development. Formative and inspiring interactions aroused emotive responses of care and encouragement for the multiplication of leadership and work for their organizations. Efficacious beliefs integrated for executive NGO leaders to boldly step forward with their organizations to create an impact.

\section{Discussion}

The key findings of this study reflected the mediating factor of mentoring toward the efficacious development of leadership, as identified within the conceptual model of this study. Current executive NGO leaders, rising executive NGO leaders, and others within the international agricultural development context should reflect on the implications of this study to determine beneficial practices to adopt. Additionally, leadership educators and leadership development professionals should observe the transferable elements of this study to their classrooms and practices. While findings of this study reflect the context of executive leaders in international agricultural development organizations, implications may be transferable to multiple contexts facing the common leadership gap with the retirement of the baby boom generation (Suarez, 2010).

Participants noted the significant role of mentors throughout their past leadership development experiences. Increasing leader efficacy through a mentoring relationship has impacted motivation to lead and is integral to continued leadership development (Lester et al., 2011). Yet, increased efficacy does not necessarily translate to practice 
(Reichard et al., 2017). Although mentoring played a significant role in the participants' leadership development on their journey to the executive leadership role, the presence of mentoring became more challenging in the executive role.

A significant shift occurred in the participants' responses from reflecting upon mentor influence to the influence of a peer network. Peer networks enable connection for leaders facing similar challenges and contexts, thus opportunities for improved leadership self-efficacy and collaborative efforts to address complex challenges (Mercier, 2012; Siebert et al., 2017). Intentional effort for leadership development can help alleviate the growing leadership gap within the NGO sector (Carman et al., 2010; Froelich et al., 2011; Suarez, 2007).

Findingsofthisstudyindicatevariousrolesofmentoring in executive NGO leader development experiences. Participants' leadership development experiences through mentoring along their journey to executive leadership has implications for the overarching role of mentoring in leadership development. The minimal experiences with mentoring within participants' current executive leadership roles, however, implies a lack of viable mentors or lack of a viable structure for formal mentoring within international agricultural development at the executive level. Subsequently, participants emphasized the establishment of a peer community or network for continued leadership development; this implies a need for continued leadership development and a support structure to be developed and leveraged through umbrella organizations, such as The Accord Network, with trusted communities of executive leaders within similar contexts.

Findings and implications of this study regarding mentoring support and reflect the conceptual model of this study, which noted mentoring as a mediating factor for leadership development. Given the leadership gap reaching across industries (Carman et al., 2010; Santora et al., 2015; Suarez, 2010; Tierney, 2006), mentoring has transferable implications for practice within the broader contexts of education and leadership development (Lester et al., 2011; Reichard et al, 2017; Siebert et al., 2017).

While individual strategies among each of these stakeholder communities will affect progress for leadership succession preparation, integrative practices can strengthen and create a more efficient means of preparing the needed leaders within nonprofits and throughout businesses, organizations, and education (Bozer et al., 2015; Froelich et al., 2011; Landles-Cobb et al., 2015; Santora et al., 2015). Just as Bandura's (1986) model of reciprocal determinism and the conceptual model for this study demonstrated the interactive nature of personal, behavioral, and environmental elements, key stakeholders in leadership development (leadership educators, leadership development practitioners, executive NGO leaders) should interact in a reciprocal nature that is mutually beneficial.

Executive coaching, mentoring, and organizational advising practices also present numerous opportunities for leadership development collaborations among executives, educators, and practitioners. Leadership educators and executives should partner in research for informed methods of leadership development; partnership would encourage strategic and mutually beneficial work that would otherwise be a hindrance to one of the parties. Leadership educators could also engage executive NGO leaders or their organizations in strategic means for course examples, guest lectures, or handson experience for students to engage with a NGO for service-learning or creating custom leadership development tools; leadership development practitioners could serve as reviewers of the endeavor. Utilizing the tendency to form networks or communities as a leadership development practice can be enhanced with intentional means of accountability for individual development plans (Froelich et al., 2011; Landles-Cobb et al., 2015; Sherlock \& Nathan, 2007). 


\section{Recommendations \& Conclusion}

Considering the insights gleaned from this study, there are several opportunities for future research to explore various aspects of executive NGO leadership development within international agricultural development. Research regarding various interventions to positively impact leadership self-efficacy development is needed (Anderson et al., 2008; Chan \& Drasgow, 2001; Day \& Dragoni, 2015; Walumbwa et al., 2005). This future research would also support further development of the conceptual model proposed in this study. Mediating factors for leadership development can also be explored at the organizational level to determine best practices (Petridou et al., 2017; Reichard et al., 2017). Established best practices would also aid in determining the effectiveness and efficiency of various leadership development practices (Day et al., 2014; Hervy \& Gilboy, 2014).

Mentoring has been promoted as a beneficial tool for leader development, yet very few empirical studies have explored the practice in light of leader selfefficacy and leadership development (Helber, 2015; Jnah \& Robinson, 2015; Lester et al., 2011; MoererUrdahl \& Creswell, 2004; Siebert et al., 2017). Findings of this study indicated the integral role mentoring played for participants' leadership development. Further research is needed to determine the extent of the role mentoring plays within leadership development and the development of leadership selfefficacy for executive NGO leaders in international agricultural development. The representation of faith-based organizations within this study reflects the intertwined influence of religion and international agricultural development work throughout history (Lunn, 2009; Rakodi, 2012; Raney \& Raveloharimisy, 2016). Further research is needed to explore the role of faith within mentoring practices as a factor for leadership development. Additional research across various sectors regarding the impact of mentoring on leadership development would benefit the broader research base of leadership development and leadership education. 


\section{References}

Anderson, D. W., Krajewski, H. T., Goffin, R. D., \& Jackson, D. N. (2008). A leadership self-efficacy taxonomy and its relation to effective leadership. The Leadership Quarterly, 19(5), 595-608. https://doi.org/10.1016/j. leaqua.2008.07.003

Ary, D., Jacobs, L. C., Sorensen, C., \& Razavieh, A. (2010). Introduction to research in education (8th ed.). Cengage Learning.

Ball, S. F. (2017). A phenomenological study of the lived experiences of nurse educators with prior military careers [Doctoral dissertation, Liberty University]. Scholars Crossing. https://digitalcommons.liberty.edu/ doctoral/1417

Bandura, A. (1977). Self-efficacy: Toward a unifying theory of behavioral change. Psychological Review, 84(2), 191-215. https://doi.org/10.1037/0033-295X.84.2.191

Bandura, A. (1986). Social foundations of thought and action: A social cognitive theory. Prentice-Hall.

Bandura, A. (1998). Personal and collective efficacy in human adaptation and change. In J. G. Adair, D. Belanger, \& K. L. Dion (Eds.), Advances in psychological science: Vol. 1. Personal, social and cultural aspects (pp. 51-71). Psychology Press.

Bang, H. \& Reio, T. G. (2017). Personal accomplishment, mentoring, and creative self-efficacy as predictors of creative work involvement: The moderating role of positive and negative affect. The Journal of Psychology, 151(2), 148-170. https://doi.org/10.1080/00223980.2016.1248808

Bozer, G., Kuna, S., \& Santora, J. C. (2015). The role of leadership development in enhancing succession planning in the Israeli nonprofit sector. Human Service Organizations: Management, Leadership \& Governance, 39(5), 492-508. https://doi.org/10.1080/23303131.2015.1077180

Caligiuri, P. M. \& Dragoni, L. (2015). Global leadership development. In D. G. Collings, G. T. Wood, \& P. M. Caligiuri (Eds.), The Routledge Companion to International Human Resource Management (pp. 226-239). Routledge.

Carman, J. G., Leland, S. M., \& Wilson, A. J. (2010). Crisis in leadership or failure to plan? Insights from Charlotte, North Carolina. Nonprofit Management \& Leadership, 21(1), 93-111.

Chan, K. \& Drasgow, F. (2001). Toward a theory of individual differences and leadership. Journal of Applied Psychology, 86(3), 481-498. https://doi.org/10.1037/0021-9010.86.3.481

Creswell, J. W. (2012). Qualitative inquiry and research design: Choosing among five approaches (3rd ed.). Sage.

Day, D. V. \& Dragoni, L. (2015). Leadership development: An outcome-oriented review based on time and levels of analyses. Annual Review of Organizational Psychology and Organizational Behavior, 2, 133-156. https://doi.org/10.1146/annurev-orgpsych-032414-111328

Day, D. V., Fleenor, J. W., Atwater, L. E., Sturm, R. E., \& McKee, R. (2014). Advances in leader and leadership development: A review of 25 years of research and theory. The Leadership Quarterly, 25(1), 63-82. https:// doi.org/10.1016/j.leaqua.2013.11.004 
Food and Agriculture Organization of the United Nations, International Fund for Agricultural Development, and World Food Programme. (2015). The State of Food Insecurity in the World. Meeting the 2015 international hunger targets: taking stock of uneven progress. Food and Agriculture Organization of the United Nations. http://www.fao.org/3/i4646e/i4646e.pdf

Froelich, K., McKee, G., \& Rathge, R. (2011). Succession planning in nonprofit organizations. Nonprofit Management \& Leadership, 22(1), 3-20. https://doi.org/10.1002/nml.20037

Garmon, K. M. (2007). Antecedents of self-efficacy beliefs: A phenomenological investigation of women leaders in the credit union industry [Unpublished doctoral dissertation]. Regent University.

Guba, E. G. (1981). Criteria for assessing the trustworthiness of naturalistic inquiries. Educational Communication and Technology, 29(2), 75-91. https://doi.org/10.1007/BF02766777

Hannah, S. T., Avolio, B. J., Luthans, F. \& Harms, P. D. (2008). Leadership efficacy: Review and future directions. The Leadership Quarterly, 19(6), 669-692. https://doi.org/10.1016/j.leaqua.2008.09.007

Helber, J. D. (2015). Self-efficacy and instructional leadership: Does mentoring make a difference? [Doctoral dissertation, Eastern Michigan University]. Eastern Michigan Commons. https://commons.emich.edu/ theses/616/

Hervy, A., \& Gilboy, A. (2014, February). Good Practices in Leveraging Long-term Training for Institutional Capacity Strengthening. Association of Public and Land-Grant Universities, Knowledge Center on Higher Education for African Development. https://www.aplu.org/library/good-practices-in-leveraging-long-termtraining-for-institutional-capacity-strengthening/file

Javidan, M., Bullough, A., \& Dibble, R. (2016). Mind the gap: Gender differences in global leadership selfefficacies. Academy of Management Perspectives, 30(1), 59-73. https://doi.org/10.5465/amp.2015.0035

Jnah, A. J. \& Robinson, C. B. (2015). Mentoring and self-efficacy: Implications for the neonatal nurse practitioner workforce. Advances in Neonatal Care, 15(5), E3-E11. https://doi.org/10.1097/ ANC.0000000000000227

Landles-Cobb, L., Kramer, K., \& Milway, K. S. (2015, October 22). The nonprofit leadership development deficit. Stanford Social Innovation Review. https://ssir.org/articles/entry/the_nonprofit_leadership_development_ deficit

Lester, P. B., Hannah, S. T., Harms, P. D., Vogelgesang, G. R., \& Avolio, B. J. (2011). Mentoring impact on leader efficacy development: A field experiment. Academy of Management Learning \& Education, 10(3), 409429. https://doi.org/10.5465/amle.2010.0047

Lewis, D. \& Opoku-Mensah, P. (2006). Moving forward research agendas on international NGOs: Theory, agency and context. Journal of International Development, 18(5), 665-675. https://doi.org/10.1002/jid.1306

Lunn, J. (2009). The role of religion, spirituality and faith in development: A critical theory approach. Third World Quarterly, 30(5), 937-951. https://doi.org/10.1080/01436590902959180

Machida, M. \& Feltz, D. L. (2013). Studying the advancement of women coaches: The roles of leader selfefficacy. International Journal of Coaching Science, 7(2), 53-71. 
Machida, M. \& Schaubroeck, J. (2011). The role of self-efficacy beliefs in leader development. Journal of Leadership and Organizational Studies, 18(4), 459-468. https://doi.org/10.1177/1548051811404419

McCormick, M. J. (2001). Self-efficacy and leadership effectiveness: Applying social cognitive theory to leadership. The Journal of Leadership Studies, 8(1), 22-33. https://doi.org/10.1177/107179190100800102

Mercier, S. (2012, November). U.S. Agricultural Development Assistance and Food Aid: Programs and Issues. AGree.

Moerer-Urdahl, T. \& Creswell, J. W. (2004). Using transcendental phenomenology to explore the "ripple effect" in a leadership mentoring program. International Journal of Qualitative Methods, 3(2), 19-35. https:// doi.org/10.1177/160940690400300202

Montas-Hunter, S. S. (2012). Self-efficacy and Latina leaders in higher education. Journal of Hispanic Higher Education, 11(4), 315-335. https://doi.org/10.1177/1538192712441709

Moustakas, C. (1994). Phenomenological research methods. Sage.

Nyukorong, R. \& Quisenberry, W. (2016). Character traits of effective executives: A phenomenological study of CEOs in Ghana. European Scientific Journal, 12(20), 69-90. https://doi.org/10.19044/esj.2016.v12n20p69

Paglis, L. L. \& Green, S. G. (2002). Leadership self-efficacy and managers' motivation for leading change. Journal of Organizational Behavior, 23(2), 215-235. https://doi.org/10.1002/job.137

Payne, J. D. (2013). Pressure Points: Twelve global issues shaping the face of the church. Thomas Nelson.

Petridou, A., Nicolaidou, M., \& Karagiorgi, Y. (2017). Exploring the impact of professional development and professional practice on school leaders' self-efficacy: a quasi-experimental study. School Effectiveness and School Improvement, 28(1), 56-73. https://doi.org/10.1080/09243453.2016.1236734

Phan, N. T. \& Locke, T. (2015). Sources of self-efficacy of Vietnamese EFL teachers: A qualitative study. Teaching and Teacher Education, 52, 73-82. https://doi.org/10.1016/j.tate.2015.09.006

Rakodi, C. (2012). A framework for analyzing the links between religion and development. Development in Practice, 22(5-6), 634-650. https://doi.org/10.1080/09614524.2012.685873

Raney, A. \& Raveloharimisy, J. (2016). The contributions of faith-based organizations to development and the humanitarian field: An ADRA case study. Interdisciplinary Journal of Best Practices in Global Development, 2(1), 1-16. https://knowledge.e.southern.edu/ijbpgd/vol2/iss1/2

Reichard, R. J., Walker, D. O., Putter, S. E., Middleton, E. \& Johnson, S. K. (2017). Believing is becoming: The role of leader developmental efficacy in leader self-development. Journal of Leadership and Organizational Studies, 24(2), 137-156. https://doi.org/10.1177/1548051816657981

Santora, J. C., Sarros, J. C., Bozer, G., Esposito, M. \& Bassi, A. (2015). Nonprofit executive succession planning and organizational sustainability: A preliminary comparative study in Australia, Brazil, Israel, Italy, Russia, and the United States. The Journal of Applied Management and Entrepreneurship, 20(4), 66-83.

Seidman, I. (2013). Interviewing as qualitative research: A guide for researchers in education and the social sciences (4th ed.). Teachers College Press. 
Sherlock, J. J. \& Nathan, M. L. (2007). Nonprofit association CEOs: How their context shapes what, how, and why they learn. Nonprofit Management \& Leadership, 18(1), 19-39. https://doi.org/10.1002/nml.169

Siebert, S. E., Sargent, L. D., Kraimer, M. L., \& Kiazad, K. (2017). Linking developmental experiences to leader effectiveness and promotability: The mediating role of leadership self-efficacy and mentor network. Personnel Psychology, 70(2), 357-397. https://doi.org/10.1111/peps.12145

Suarez, D. F. (2010). Street credentials and management backgrounds: Careers of nonprofit executives in an evolving sector. Nonprofit and Volunteer Sector Quarterly, 39(4), 696-716. https://doi. org/10.1177/0899764009350370

Tierney, T. J. (2006). The leadership deficit. Stanford Social Innovation Review. https://ssir.org/articles/entry/ the_leadership_deficit

United Nations. (2015). Transforming our world: The 2030 agenda for sustainable development. United Nations. https://sdgs.un.org/2030agenda

Walumbwa, F. O., Lawler, J. J., Avolio, B. J., Wang, P., \& Shi, K. (2005). Transformational leadership and work-related attitudes: The moderating effects of collective and self-efficacy across cultures. Journal of Leadership and Organizational Studies, 11(3), 2-16.

Wood, R. \& Bandura, A. (1989). Impact of conceptions of ability on self-regulatory mechanisms and complex decision making. Journal of Personality and Social Psychology, 56(3), 407-415. https://doi.org/10.1037/00223514.56.3.407 